\title{
Historic records and GIS applications for flood risk analysis in the Salento peninsula (southern Italy)
}

\author{
F. Forte ${ }^{1}$, L. Pennetta ${ }^{1}$, and R. O. Strobl ${ }^{2}$ \\ ${ }^{1}$ Sezione di Geografia fisica e Geomorfologia - Dipartimento di Geologia e Geofisica, Università degli Studi di Bari, via E. \\ Orabona 4, 70125 Bari, Italy \\ ${ }^{2}$ ITC - International Institute for Geoinformation Science and Earth Observation, Hengelosestraat 99, 7514 AE Enschede, \\ The Netherlands
}

Received: 17 November 2004 - Revised: 13 October 2005 - Accepted: 19 October 2005 - Published: 2 November 2005

\begin{abstract}
The occurrence of calamitous meteoric events represents a current problem of the Salento peninsula (Southern Italy). In fact, flash floods, generated by very intense rainfall, occur not only in autumn and winter, but at the end of summer as well. These calamities are amplified by peculiar geological and geomorphological characteristics of Salento and by the pollution of sinkholes. Floodings affect often large areas, especially in the impermeable lowering zones. These events cause warnings and emergency states, involving people as well as socio-economic goods.

A methodical investigation based on the historic flood records and an analysis of the geoenvironmental factors have been performed, using a Geographic Information System (GIS) methodology for database processing in order to identify the distribution of areas with different risk degrees. The data, referring to events that occurred from 1968 to 2004, have been collected in a database, the so-called IPHAS (Salento Alluvial PHenomena Inventory), extracted in an easily consultable table. The final goal is the development of a risk map where the areas that are affected by floodings are included between small ridges, the so-called "Serre". More than $50 \%$ of the Salento peninsula shows high or very high risk values. The numerous maps that were utilized and generated represent an important basis in order to quantify the flood risk, according to the model using historic records.
\end{abstract}

\section{Introduction}

\subsection{Foreward}

This paper has been extracted from a PhD thesis submitted in the Department of Geology and Geophysics of Bari University and deals with flood phenomena which occur periodically in the Salento peninsula (southern Italy), causing warn-

Correspondence to: F. Forte

(geoforte@libero.it) ing and emergency states to the population and economic activity.

\subsection{Geological and geomorphological settings}

The Salento peninsula, the southeast portion of the Apulia region (southern Italy), covers $7000 \mathrm{~km}^{2}$ of area and stretches over $150 \mathrm{~km}$ between the Ionian and Adriatic seas (Fig. 1). The peninsula includes two extreme geographical points: the Punta Palascìa, near Capo d'Otranto and the Punta Rìstola, near Capo S. Maria di Leuca, in the final strip of the Apulia region.

Geologically, the substratum of the Salento peninsula is a carbonatic shelf, $6000 \mathrm{~m}$ thick, represented by limestone, dolomitic limestone and dolomite strata, originating from the Jurassic to the Upper Cretaceous (Maastrichtian) periods (Ricchetti, 1988; De Giorgi, 1884, 1922, 1960). In the lowering zones, there are impermeable mio-plio-pleistocenic sediments with clay insertions which stand on limestone, dolomitic limestone and dolomite (Ciaranfi et al., 1988; Largaiolli et al., 1969) (Fig. 2).

Morphologically, the Salento area is a flat area with elevations just above sea level. It is characterized by small ridges, the so-called "Serre salentine", extending in a SE-NW direction (Martinis, 1962, 1967a, b, 1970). They had originated by tectonic stresses acting during the Cretaceous period until the Upper Pleistocene period, mainly along SSE-NNW and SSW-NNE directions, resulting in slopes of normal fault and, therefore, Horst and Graben structures (Battista et al., 1985) (Fig. 3).

The landforms described represent the main aspect of "Terra d'Otranto", but not the only one: in fact, also the rainfall effects and karstic phenomena are easily recognizable in this landscape.

Furthermore, on the Salento peninsula two kinds of streams can be distinguished: on the one hand, an endoreic type, which is comprised by relatively wider canals and on the other hand, an exoreic one, which is represented by small canals, but hierarchized (Battista et al., 1985). The endoreic 


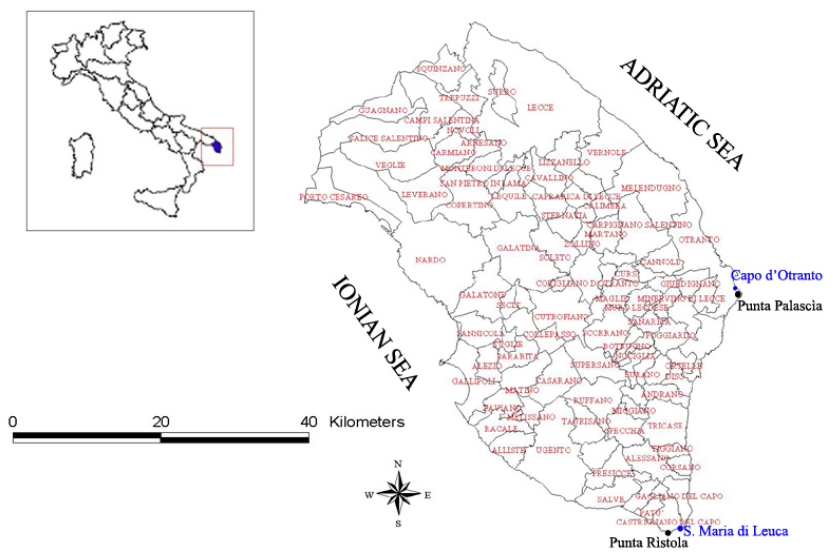

Fig. 1. Municipal limits.

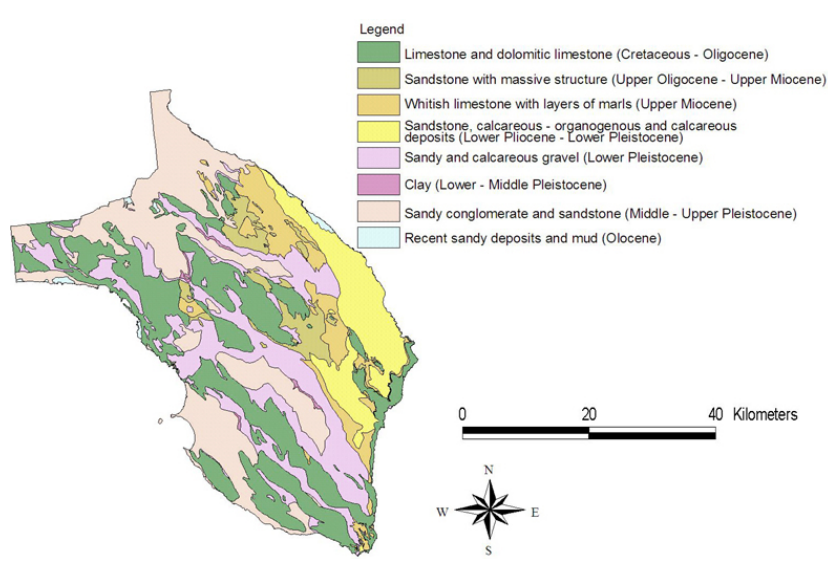

Fig. 2. Geolithological map of Salento peninsula.

network, represented by canals, the so - called "Asso" canals, is asymmetric and aligned along a SSE-NNW direction. It is converging towards a natural karstic sinkhole, the so - called "Vora Colucci", near Leverano municipality. The channels in the exoreic network, in turn, are in many places deep and located in the coastal zone. This network is conditioned by tectonic stresses. Numerous small valleys are parallel to each other, but perpendicular to the coastline (Fig. 4).

These peculiar geological and morpho-structural characteristics make some areas of the Salento peninsula susceptible to floodings, mainly when the rainfall is very intense.

\subsection{The rainfall distribution on the Salento peninsula}

Rainfalls that are very intense but short are the main cause of flood occurrences. Generally, the climate of the Salento peninsula can be defined as "Mediterranean". The rainfall is not homogeneous, so that areas with different rainfall distributions can be recognized in the Salento peninsula. This concept has been exposed already by De Giorgi (1884), Colamonico (1917, 1956), Bissanti (1968) and subsequently by Zito et al. (1988). The processing of rainfall data shows that high values of annual mean rainfall are concentrated in the eastern

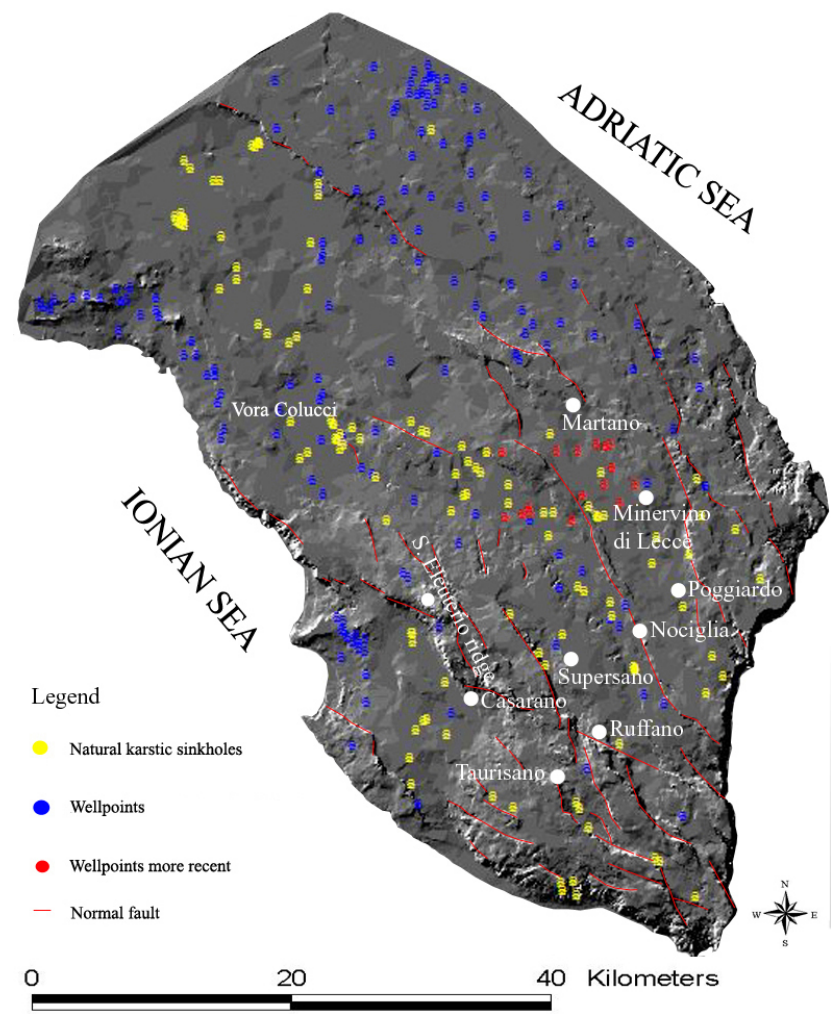

Fig. 3. DTM (Digital Terrain Model) of Salento peninsula from the isolines of 1956.

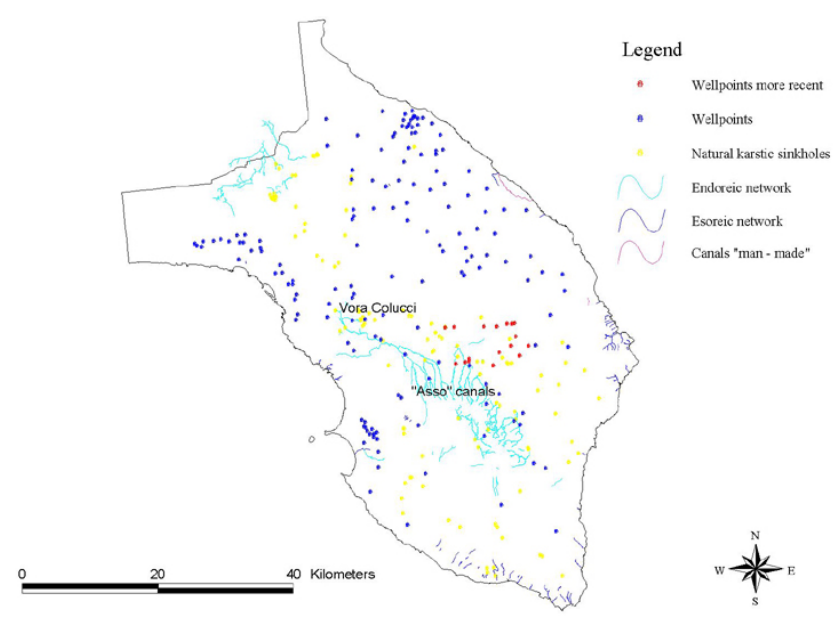

Fig. 4. Location of karstic sinkholes, wellpoints and main drainage canals.

part of Salento, where $790 \mathrm{~mm} /$ year of rainfall are registered on average. On the other hand, low values of mean annual rainfall are concentrated $(590 \mathrm{~mm} /$ year $)$ in the western part (Fig. 5). Figure 5 was obtained by an interpolation method in a GIS (Geographic Information System) software and depicts the distribution of mean annual rainfall values and the location of 14 pluviometric stations, continuously in operation since 1921. However, recently, the average rainfall has strongly decreased, giving rise to a long period of drought 

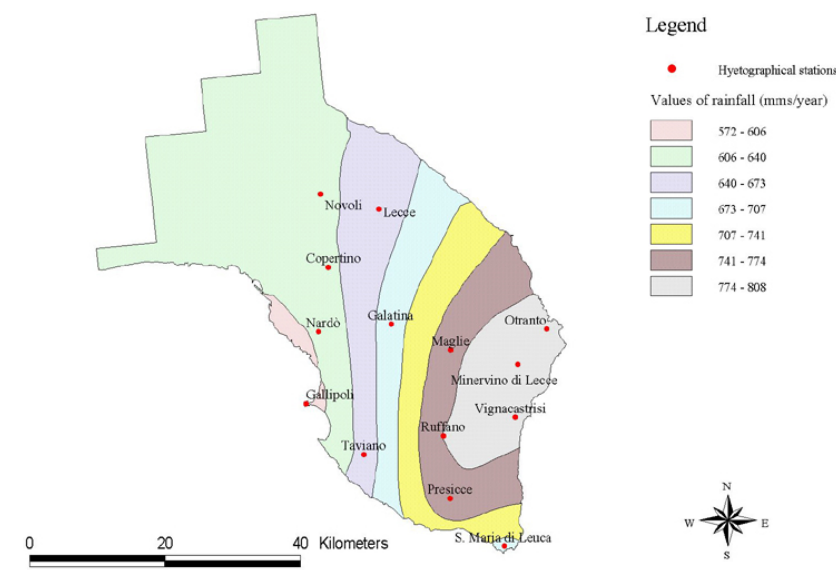

Fig. 5. Rainfall map of Salento peninsula.

(Arnell, 1999). The results obtained from a recent study of Zito (1989) show that drought periods of 50 consecutive days occur very frequently in summer, in the Salento peninsula. For instance, at Gallipoli municipality, these drought spells occur every two years, while at Otranto municipality, every 3.1 years. Therefore, the Salento area actually shows climatic characteristics which can be defined as almost semiarid (temperatures over $40^{\circ} \mathrm{C}$ and insufficient precipitation); the dryness is concentrated in the summer months, whereas the rainfall is mainly concentrated in autumn-winter, but also at the end of summer (Battista et al., 1987).

However, in Salento, the meteorological changes are very frequent, giving the climate a characteristic of an "unstable whim", already recognized by Costa (1834), two centuries ago.

\section{Methods}

In a similar study of flood hazard and risk, a methodical investigation based on the historic flood records (Cook, 1987; OFDA, 1996; CNR - GNDCI, 1998; Spaliviero, 2003) and an analysis of the geoenvironmental factors have been performed (Bersani, 2004). Such an analysis is undertaken through the mapping of these geoenvironmental factors, where the classes are defined by numerical indices. This model has been improved by means of techniques and instruments of data acquisition: particularly, through the development of statistical packages applied to the different factors as well as through GIS softwares, used for the management and processing of georeferenced data for large areas (Johnston, 1998; Meijerink et al., 2003; Daniels, 2003). Consequently, the method can be articulated in five research phases:

- Identification of the flood distribution at a scale of 1:25,000 (maps showing flood susceptibility and flood locations);

- Detailed study of geoenvironmental factors and causes determining the natural disasters;

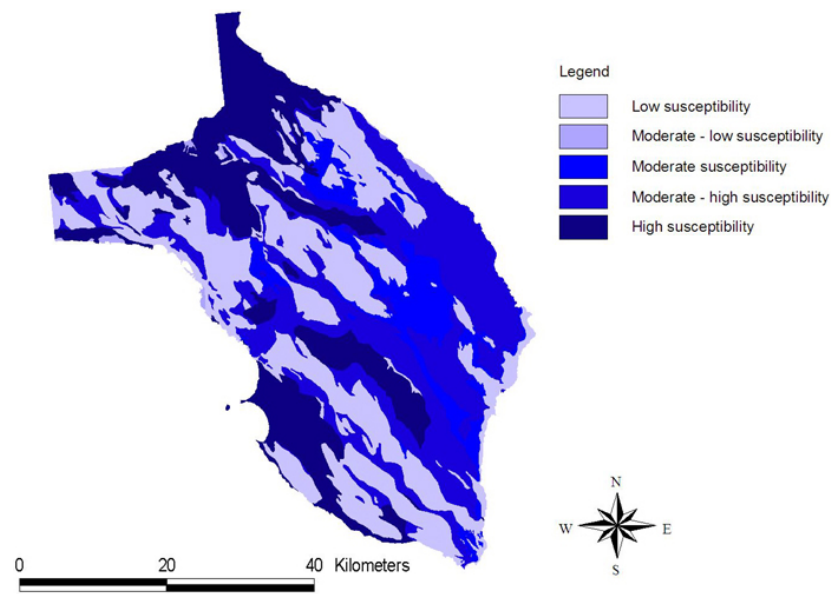

Fig. 6. "Susceptibility to flood" map of Salento peninsula.

- A "return times" calculation;

- Identification of the elements at risk and vulnerability, depending on the expected damage;

- Analysis of the flood risk, expressed by indices.

The initial phase of this research effort has entailed the creation of an alphanumerical database, the so-called IPHAS (Salento Alluvial PHenomena Inventory), in which the municipalities affected by floodings in the time interval from 1968 to 2004 have been catalogued. For the data processing, data of the AVI (Italian Vulnerable Areas) project of CNRGNDCI (National Council of Research) for the time interval of 1968-1999 as well as data of local/national newspapers ("Gazzetta del Mezzogiorno", "Quotidiano di Lecce", "La Repubblica" and "Il Messaggero") and data of a field survey conducted for the subsequent time interval 1999-2004, have been taken into account and integrated. A map showing flood susceptibility has been computed (Fig. 6). The production of this map has considered the environmental factors leading to floods (lithology and the fracture network of the stratigraphic units, slope and runoff) and is used to create digital models in order to attribute susceptibility rates. The environmental susceptibility is given by the addition of susceptibility rates (Carrozzo et al., 2003). In addition, a flood location map (Fig. 7) at a scale of 1:25000 has been mapped over the DTM. These maps, supported by a geolithological map, permeability map and rainfall map, have allowed to identify the hazard factor and the hazard areas. With regard to the flood vulnerability factor, the land - use map was linked with the flood location map and the 'susceptibility to flood' map. By crossing hazard and vulnerability factors, and subsequently using indices obtained from the ArcGIS 8.3 software in order to identify the risk classes, the flood risk was mapped. Furthermore, this developed model has been based on a field survey, an aerial photos study, an interpretation of a DTM sequence and rainfall data analysis. Mean annual and hourly rainfall data were compiled for the time period of 1968 until 1996. Rainfall data from 1996 until today were 


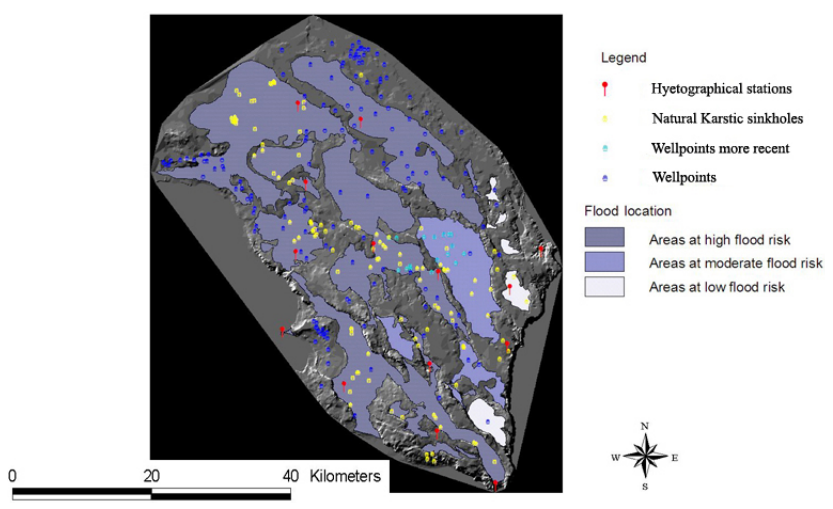

Fig. 7. Flood location map on DTM (Digital Terrain Model) of Salento peninsula.

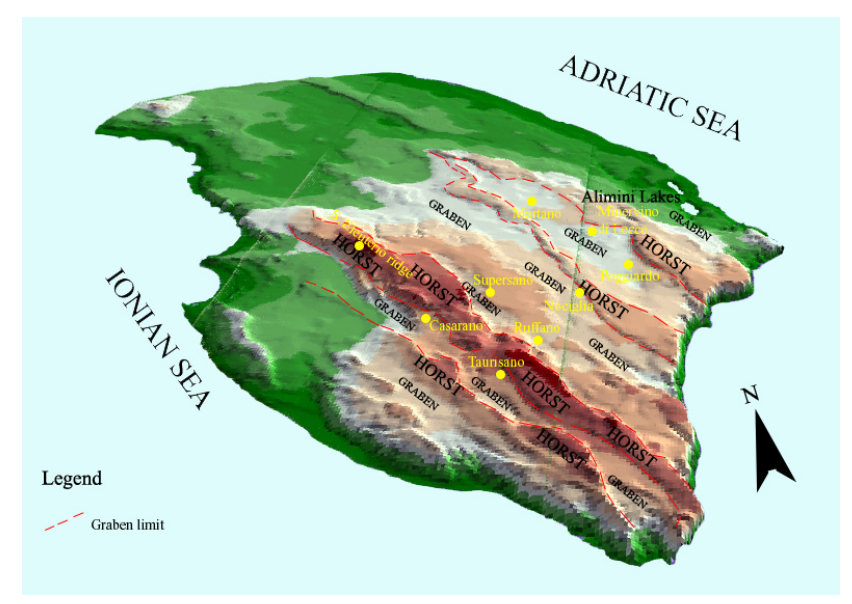

Fig. 8. DTM (Digital Terrain Model) of Salento peninsula from the isolines of 1976 .

not available. With regard to the DTM sequence, the first one (Fig. 3) is computed from the isolines of an aerial photos survey of 1956, while the second one (Fig. 8) is computed from the isolines of an aerial photos survey of 1976. The difference between the DTMs shows the topographical evolution of Salento in time and space. In fact, small differences can be observed, mainly below the ridges. These differences probably are due to agricultural and pastoral activity as well as waterflows. In fact, very intense rainfall erodes the alluvium of a slope fault. The alluvium, transported by water, is redeposited in the lowering zones, filling them slowly and entirely after each flood event. This observation of a continuous slow migration of the lowering zones is important in order to classify the floodings, mainly in terms of the morphometry of floodings and the hydraulic parameters and characteristics (Forte, 2005).

An inspection of the DTM of Fig. 8 reveals that the morphology includes Horst and Graben structures, two lowering zones generated by tectonic stresses and presently occupied by lakes, the so-called Alimini lakes. In turn, an inspection of the 3D model of Fig. 3 reveals the topography of Salento, with a double system of normal faults and the distribution

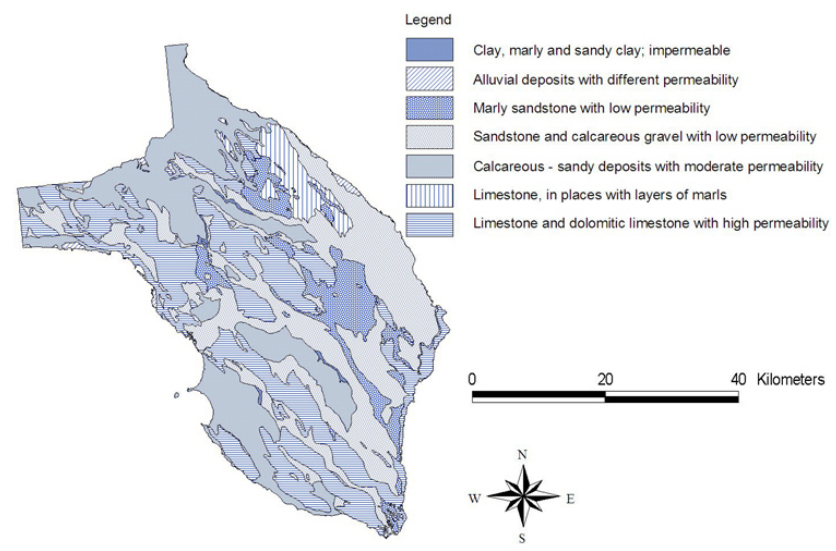

Fig. 9. Sketch of permeability map of Salento peninsula.

of the mainly karstic sinkholes and wellpoints. Even though Salento is a karstic region, practically without streams, some areas are periodically inundated because the sinkholes and drainage canals, frequently polluted, do not allow for the absorption or further conveyance of rainfall. The floodings cause damage to economic goods in the urban and suburban areas that are located in the lowering zones, where impermeable sediments, such as silt and clay, hinder floods (Fig. 9).

\section{Results}

\subsection{Flood hazard assessment}

Hazard mapping is an essential step in the determination of the past and potential locations of flooded areas (Landesman, 2001). With regard to the evaluation of the environmental hazard, a model in GIS software based on index assessment has been adopted in the past (Bolt, 1975). Such an approach takes into consideration the environmental factors causing the flood conditions (Carrozzo et al., 2003). These are the following: 1) permeability of lithological units; 2) slope and 3) flood location.

With regard to the hazard index of permeability of the lithological units, the floodings occur on every lithological unit. However, the floodings are more extensive on silt and clay than on limestone and sandstone, resulting in higher index values for the silt and clay units. With respect to the hazard index of slope, the floodings occur more frequently on flat areas than on slopes, thus leading to higher index values for flat areas. Finally, with regard to the hazard index of flood location, the distance from drainage canals and sinkholes/wellpoints has been considered. Areas nearest to sinkholes/wellpoints and drainage canals are more frequently flooded and, therefore, the index of hazard is assigned a higher value (Mijatovic, 1987; Molina et al., 1987; Andah et al., 1998; Hudson, 2003).

Commencing with these literature data, the characteristics of rainfall (mainly very intense but short rainfall, expressed as average monthly rainfall) have been considered in order 


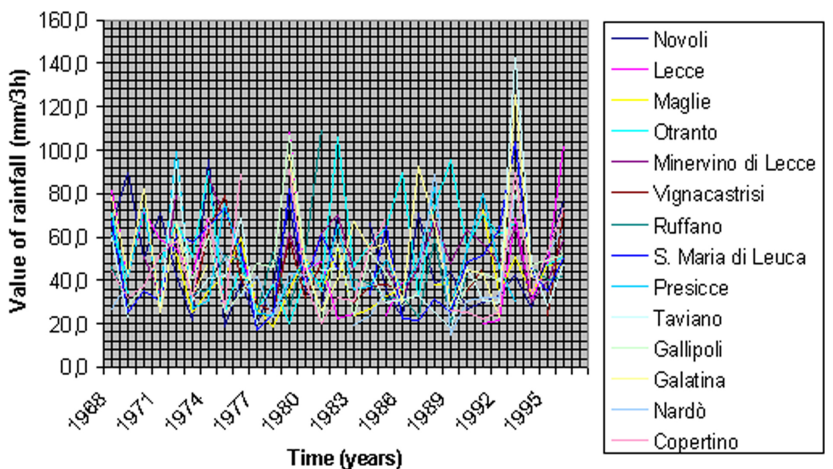

Fig. 10. Annual trend of rainfall with reference to a time period of $3 \mathrm{~h}$.

Table 1. Values of return time ( $T_{r}$, in years) and number of flood events $(N)$ extracted from "IPHAS" historic database.

\begin{tabular}{|c|c|c|c|c|c|}
\hline & $T_{r}$ & $N$ & & $T_{r}$ & $N$ \\
\hline Acquarica del Capo & 12 & 3 & Monteroni di Lecce & 12 & 3 \\
\hline Alessano & 18 & 2 & Morciano di Leuca & 18 & 2 \\
\hline Alliste & 18 & 2 & Muro Leccese & 12 & 3 \\
\hline Aradeo & 12 & 3 & Nardò & 5.1 & 7 \\
\hline Calimera & 36 & 1 & Nociglia & 12 & 3 \\
\hline Campi Salentina & 7.2 & 5 & Novoli & 18 & 2 \\
\hline Caprarica di Lecce & 36 & 1 & Otranto & 36 & 1 \\
\hline Carmiano & 18 & 2 & Parabita & 36 & 1 \\
\hline Casarano & 9 & 4 & Patù & 36 & 1 \\
\hline Castrì di Lecce & 36 & 1 & Poggiardo & 6 & 6 \\
\hline Castro & 36 & 1 & Porto Cesareo & 18 & 2 \\
\hline Cavallino & 9 & 4 & Presicce & 36 & 1 \\
\hline Collepasso & 12 & 3 & Racale & 18 & 2 \\
\hline Copertino & 5.1 & 7 & Ruffano & 9 & 4 \\
\hline Corigliano d'Otranto & 18 & 2 & SanCesario di Lecce & 36 & 1 \\
\hline Corsano & 18 & 2 & San Donato di Lecce & 18 & 2 \\
\hline Cutrofiano & 36 & 1 & San Foca & 36 & 1 \\
\hline Galatina & 7.2 & 5 & San Pietro in Lama & 36 & 1 \\
\hline Galàtone & 18 & 2 & Salice salentino & 18 & 2 \\
\hline Gallipoli & 4 & 9 & San Cassiano & 36 & 1 \\
\hline Giurdignano & 3 & 1 & Sanarica & 12 & 3 \\
\hline Lecce & 2.4 & 15 & Scorrano & 7.2 & 5 \\
\hline Lequile & 36 & 1 & Soleto & 18 & 2 \\
\hline Leverano & 9 & 4 & Spongano & 36 & 1 \\
\hline Lizzanello & 18 & 2 & Squinzano & 5.1 & 7 \\
\hline Lucugnano & 36 & 1 & Sternatìa & 18 & 2 \\
\hline Maglie & 4.5 & 8 & Supersano & 9 & 4 \\
\hline Marina di Sant'Isidoro & 36 & 1 & Surbo & 9 & 4 \\
\hline Marina di Torre Lapillo & 12 & 3 & Taurisano & 12 & 3 \\
\hline Marittima di Diso & 36 & 1 & Trepuzzi & 18 & 2 \\
\hline Martano & 12 & 3 & Tricase & 7.2 & 5 \\
\hline Martignano & 36 & 1 & Tuglie & 36 & 1 \\
\hline Matino & 18 & 2 & Ugento & 12 & 3 \\
\hline Melendugno & 36 & 1 & Uggiano La Chiesa & 18 & 2 \\
\hline Melissano & 7.2 & 5 & Veglie & 36 & 1 \\
\hline Minervino di Lecce & 36 & 1 & Vèrnole & 12 & 3 \\
\hline
\end{tabular}

to assess the flood hazard. A rainfall time interval of $3 \mathrm{~h}$ has been employed in the analysis (Fig. 10). In fact, during this time interval the maximum rainfall intensity can be obtained, as well as the return time $T_{r}$ (Table 1). $T_{r}$ represents the av-
Table 2. Values of frequency $\left(F_{r}\right)$ of floodings.

\begin{tabular}{llll}
\hline & $F_{r}$ & & $F_{r}$ \\
\hline Acquarica del Capo & 0.083 & Monteroni di Lecce & 0.083 \\
Alessano & 0.055 & Morciano di Leuca & 0.055 \\
Alliste & 0.055 & Muro Leccese & 0.083 \\
Aradeo & 0.083 & Nardò & 0.196 \\
Calimera & 0.027 & Nociglia & 0.083 \\
Campi Salentina & 0.138 & Novoli & 0.055 \\
Caprarica di Lecce & 0.027 & Otranto & 0.027 \\
Carmiano & 0.055 & Parabita & 0.027 \\
Casarano & 0.111 & Patù & 0.027 \\
Castrì di Lecce & 0.027 & Poggiardo & 0.166 \\
Castro & 0.027 & Porto Cesareo & 0.055 \\
Cavallino & 0.111 & Presicce & 0.027 \\
Collepasso & 0.083 & Racale & 0.055 \\
Copertino & 0.196 & Ruffano & 0.111 \\
Corigliano d'Otranto & 0.055 & S.anCesario di Lecce & 0.027 \\
Corsano & 0.055 & San Donato di Lecce & 0.055 \\
Cutrofiano & 0.027 & San Foca & 0.027 \\
Galatina & 0.138 & San Pietro in Lama & 0.027 \\
Galàtone & 0.055 & Salice salentino & 0.055 \\
Gallipoli & 0.250 & San Cassiano & 0.027 \\
Giurdignano & 0.027 & Sanarica & 0.083 \\
Lecce & 0.416 & Scorrano & 0.138 \\
Lequile & 0.027 & Soleto & 0.055 \\
Leverano & 0.111 & Spongano & 0.027 \\
Lizzanello & 0.055 & Squinzano & 0.196 \\
Lucugnano & 0.027 & Sternatìa & 0.055 \\
Maglie & 0.222 & Supersano & 0.111 \\
Marina di Sant'Isidoro & 0.027 & Surbo & 0.111 \\
Marina di Torre Lapillo & 0.083 & Taurisano & 0.083 \\
Marittima di Diso & 0.027 & Trepuzzi & 0.055 \\
Martano & 0.083 & Tricase & 0.138 \\
Martignano & 0.027 & Tuglie & 0.027 \\
Matino & 0.055 & Ugento & 0.083 \\
Melendugno & 0.027 & Uggiano La Chiesa & 0.055 \\
Melissano & 0.138 & Veglie & 0.027 \\
Minervino di Lecce & 0.027 & Vèrnole & 0.083 \\
\hline & & & \\
\hline
\end{tabular}

erage period of time expected to elapse between occurrences of flood events with a given severity or higher at a particular location. $T_{r}$ was computed on the basis of the number of events occurred for each municipality in the time interval from 1968 to 2004. The frequency $F_{r}$ is inversely proportional to the return time (Table 2). The return time and the frequency are computed using

$$
\begin{aligned}
T r & =\frac{\Delta T}{N} \\
F r & =\frac{1}{T r}
\end{aligned}
$$

respectively. Although there are numerous methods to calculate the return period, for this specific study, based on historic records processing, it has been easier to use Eq. (1) in order to bypass the concept of probability of occurrence of floods. In fact, the return time represents the mean value of the time interval between two subsequent flood events.

On the other hand, the frequency has been computed from the data of the IPHAS report database. More precisely, this 
Table 3. Matrix rainfall intensity - frequency.

\begin{tabular}{ccccc}
\hline & 50 & 100 & 150 & \\
\hline 5 & 55 & 105 & 155 & \\
10 & 60 & 110 & 160 & Frequency \\
15 & 65 & 115 & 165 & \\
\multicolumn{5}{c}{ Rainfall intensity } \\
\hline
\end{tabular}

has been accomplished by counting how many times $N$ a given municipality has been affected by floodings in a time interval of $\Delta T=37$ years (1968-2004) (Table 1).

Three classes of intensity can be distinguished, by considering a time interval of $3 \mathrm{~h}$ and the mean value of rainfall per hour:

- Municipalities that register values of rainfall until $16.6 \mathrm{~mm} / \mathrm{h}$ - low intensity class;

- Municipalities that register values of rainfall from $16.6 \mathrm{~mm} / \mathrm{h}$ to $33.3 \mathrm{~mm} / \mathrm{h}$ - moderate intensity class;

- Municipalities that register values of rainfall from $33.3 \mathrm{~mm} / \mathrm{h}$ to $50 \mathrm{~mm} / \mathrm{h}$ - high intensity class.

Likewise for the rainfall frequency, there are three classes, by considering the number of flood events that had occurred in a given municipality:

- Municipalities that register cases of floods until 5 times - low frequency;

- Municipalities that register cases of floods until 10 times - moderate frequency;

- Municipalities that register cases of floods until 15 times - high frequency.

For example, it is quite natural to think that for an area having a frequency value of " 15 " and a mean value of rainfall intensity of $50 \mathrm{~mm} / \mathrm{h}$, the hazard value will be higher than for an area having a frequency value of "5" and a mean value of rainfall intensity of $16.6 \mathrm{~mm} / \mathrm{h}$.

Subsequently, the matrix "rainfall intensity-frequency" was developed (Table 3), obtaining nine indices with different hazard degrees for mapping the hazard factor (Fig. 11). Furthermore, the indices obtained by matrix computation do not give the absolute value and include some degree of subjectivity. Similarly, the areas with different hazard degrees, obtained by data processing in the ArcGIS software, do not have absolute values, but have a continuous evolution in time and space.

The derived classes in Fig. 11 show that more than 50\% of Salento has high or very high index values of environmental hazard, located mainly between the small ridges, the so-called "Serre" and in the eastern part where the rainfall exhibits maximum values.

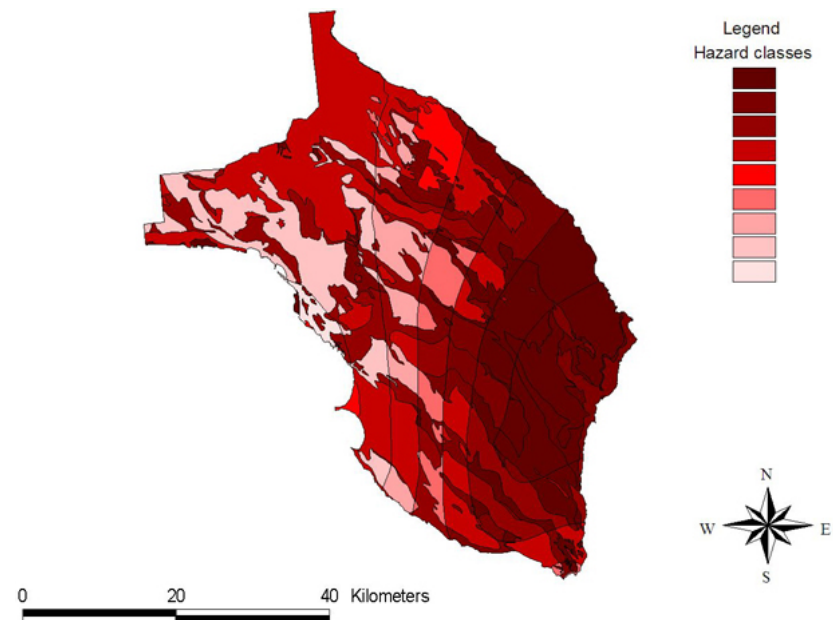

Fig. 11. Hazard flood map of Salento peninsula.

\subsection{Flood vulnerability assessment}

For the flood vulnerability assessment, the rainfall intensity has been linked to the socio-economic element at risk, distributed on the Salento peninsula and identified in the database IPHAS, under the so-called scheme "DAMAGES" (APAT, DDS (SGI), 2001) (Table 4). Where it was possible, the quality of each element has been considered (Downing, 1991). Each census application form, referring to a particular flood case in a given municipality, has it own assessment of the partial "damage degree". Therefore, the total "damage degree", calculated for each municipality in the time interval 1968-2004, is the average of the partial "damage degrees" (Wang et al., 1999).

As can be seen from the list below, the vulnerability and the damage degree have been divided into nine classes. Every element at risk has an aesthetic damage, for instance, when the function of the element affected by flooding is not impaired. When the element at risk is not functioning, it is classified as a structural damage. The different damage degrees are the following:

- No damage,

- Low aesthetic damage,

- Moderate aesthetic damage,

- High aesthetic damage,

- Low structural damage,

- Moderate structural damage,

- High structural damage,

- Dangerous damage,

- Very dangerous damage. 
Table 4. Field "damage" extracted from the "IPHAS" historic database.

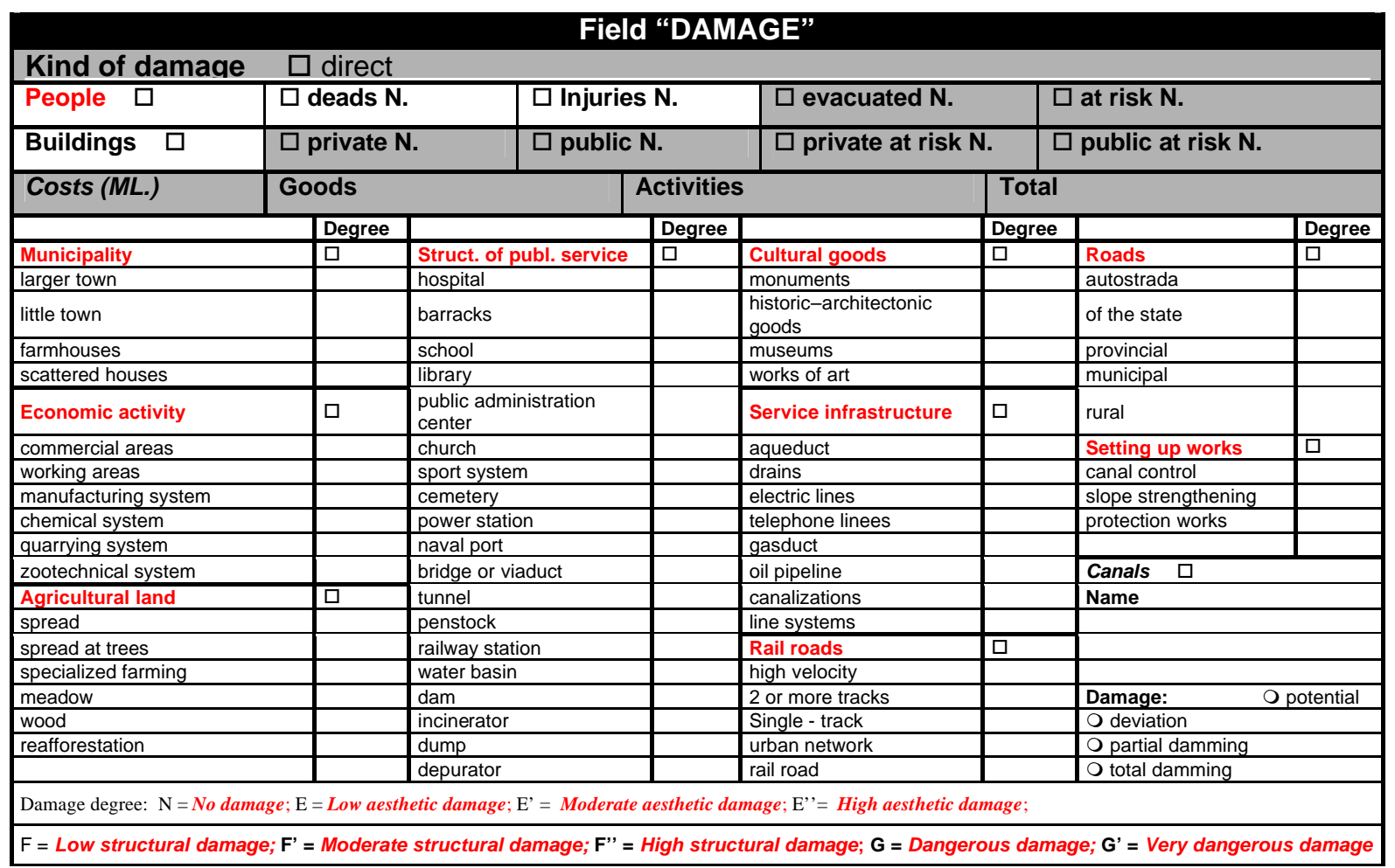

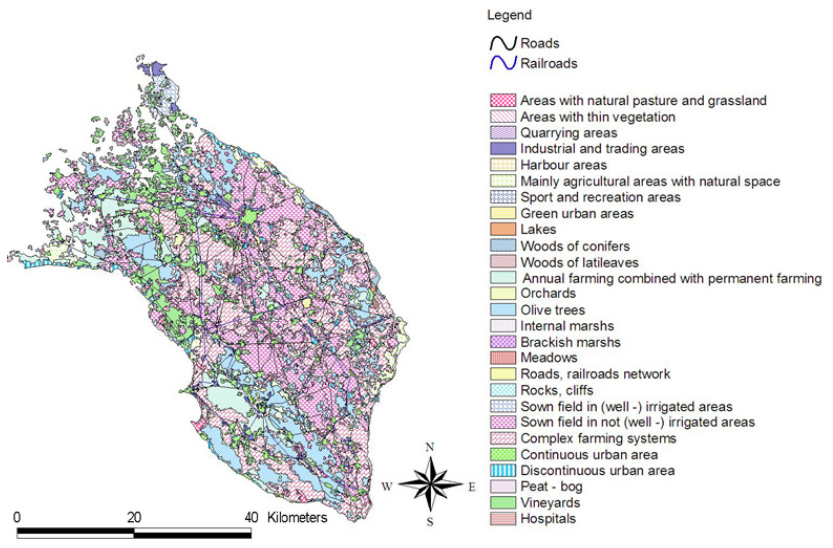

Fig. 12. Elements at Risk map of Salento peninsula.

Cartographically, the flood location map obtained by a field survey and 'susceptibility to flood' map obtained by the DTM study have been considered as well as the 'elements at risk' map with a mapping of roads and railroads (Fig. 12). Using the "overlay mapping" method through a "map query" function, the flood vulnerability map (Fig. 13) was calculated, where nine classes with different vulnerability degrees are represented.

Each class has one fictitious multiple of three indices in order that the vulnerability factor is numerically defined by values. The indices are linked with a matrix of hazard values in order to calculate the risk factor.

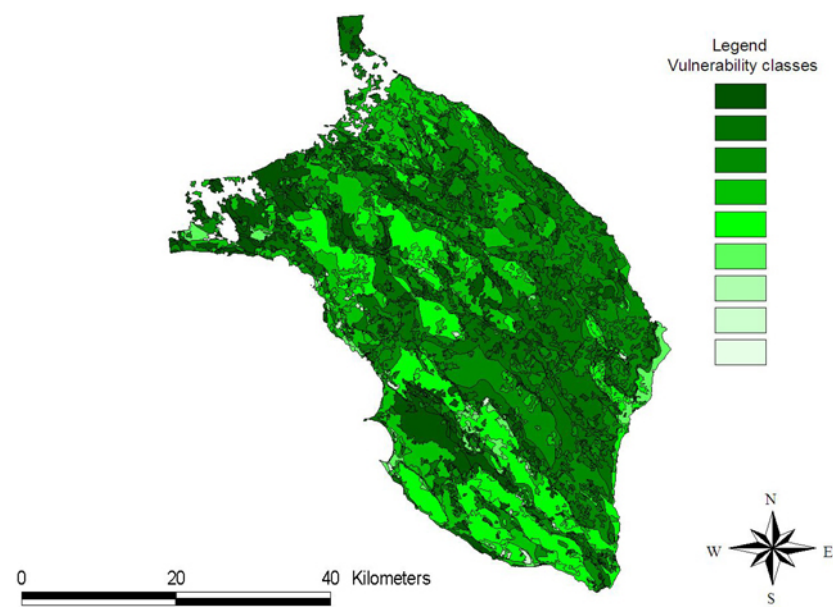

Fig. 13. Flood vulnerability map of Salento peninsula.

An inspection of Fig. 13 reveals that more than $50 \%$ of Salento has high or very high values of the vulnerability factor, also according to the values of environmental hazard. These areas are located mainly between the ridges and in the eastern part of Salento. In addition, the elements which are mostly damaged by floods, according to the elements at risk distribution of the Corine Landcover Project (1999) are the following:

1. Olive trees and tobacco, mainly cultivated in the graben areas, represent a very important regional economic resource; 
Table 5. Matrix of hazard - vulnerability factors.

\begin{tabular}{|c|c|c|c|c|c|c|c|c|c|c|}
\hline & 55 & 60 & 65 & 105 & 110 & 115 & 155 & 160 & 165 & \\
\hline 3 & 58 & 63 & 68 & 108 & 113 & 118 & 158 & 163 & 168 & \\
\hline 6 & 61 & 66 & 71 & 111 & 116 & 121 & 161 & 166 & 171 & \\
\hline 9 & 64 & 69 & 74 & 114 & 119 & 124 & 164 & 169 & 174 & \\
\hline 12 & 67 & 72 & 77 & 117 & 122 & 127 & 167 & 172 & 177 & Vulnerability \\
\hline 15 & 70 & 75 & 80 & 120 & 125 & 130 & 170 & 175 & 180 & \\
\hline 18 & 73 & 78 & 83 & 123 & 128 & 133 & 173 & 178 & 183 & \\
\hline 21 & 76 & 81 & 86 & 126 & 131 & 136 & 176 & 181 & 186 & \\
\hline 24 & 79 & 84 & 89 & 129 & 134 & 139 & 179 & 184 & 189 & \\
\hline 27 & 82 & 87 & 92 & 132 & 137 & 142 & 182 & 187 & 192 & \\
\hline \multicolumn{11}{|c|}{ Hazard } \\
\hline
\end{tabular}

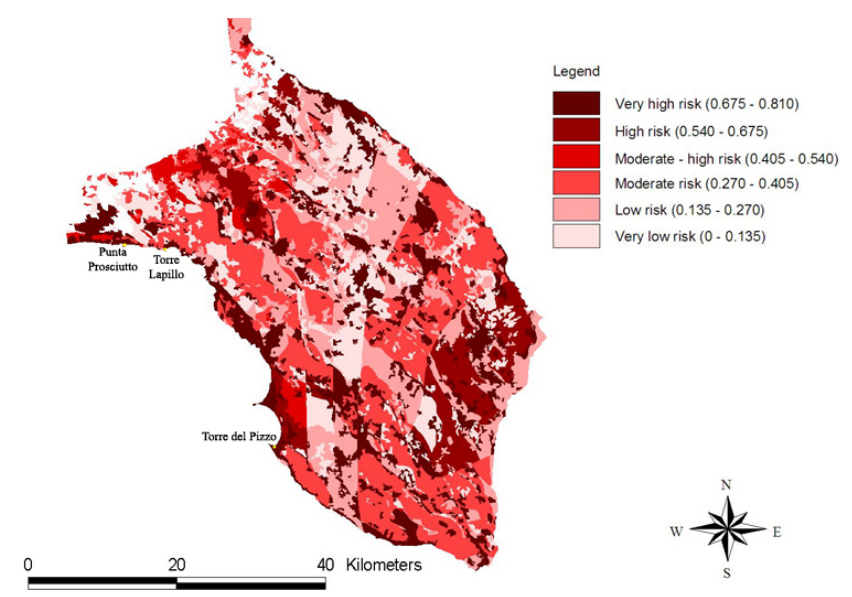

Fig. 14. Flood risk map of Salento peninsula.

2. Vineyards, located throughout but in small areas;

3. Annual farming combined with a permanent farming or complex farming system, represented by very large areas in Fig. 12;

4. Continuous/discontinuous urban areas, roads and railroads and urban/industrial areas.

5. Cultivated fields, covering large areas and located in non-irrigated zones.

Therefore, floodings affect very large agricultural areas, as well as urban/industrial areas, especially if located in the impermeable lowering zones (Khan, 2005). Obviously, the vulnerability assessment has always some degree of uncertainty and must be estimated on a case by case basis, element by element, being variable because of the parameters involved. For simplification purposes, a general subdivision of the elements at risk is considered in Table 4.

\subsection{Flood risk assessment}

The definition of Risk given by U.N.D.R.O. (United Nations Disaster Relief Office), UNESCO's Office for Disaster con- trol, needs to be recalled at this point (Coburn et al., 1994). As stated before, the flood risk $R$ is a scalar quantity which links the hazard factor, defined as the probability that a flood occurs in a given area with a determined return period, to the vulnerability factor, that is the propensity of an element (urban and industrial areas, agricultural areas, extraurban infrastructures; historical, artistic and environmental goods) to resist a particular flood (Green et al., 1989).

In order to calculate the risk factor, the hazard factor has been linked to the vulnerability and expected damage factors, according to the matrix. Subsequently, the indices, defining the areas which are characterized by a risk value, are computed (Gisotti et al., 2000) (Table 5).

Such a table shows a matrix represented by 81 indices, which in turn shows municipal areas of Salento with different flood risk values, due to flash floods.

One may think of the indices as expressed percent values, with a variability range between $1 \%$ and $81 \%$ (the matrix is represented by nine hazard indices and nine vulnerability indices). The choice of a variability range between $1-81 \%$ is not arbitrary, but justified by simplicity of computation.

Table 6 gives the percent values of flood risk, calculated for each municipality of Salento and referring to the agricultural and urban/industrial areas. The risk values obtained have some degree of uncertainty, essentially due to the subjectivity of the operator with regard to the hazard and vulnerability indices assessment (particularly for the vulnerability function, the choice of social and economic elements and its association in classes has been highly approximate and, since the elements at risk are numerous, the vulnerability assessment has been difficult).

The thematic map (Fig. 14) shows that the flood risk values have been grouped into six classes, conferring a value range between 0 and 0.81 . The indices of the hazard - vulnerability matrix have been inserted and processed with the ArcGIS software in order to calculate the flood risk (Carrozzo et al., 2003; Forte, 2005). 
Table 6. Index values of Risk $\left(R_{w}\right)$ with reference to agricultural areas and urban/industrial areas.

\begin{tabular}{|c|c|c|c|c|c|}
\hline & $R_{w}$ agricultural & $R_{w}$ urban/industrial & & $R_{w}$ agricultural & $R_{w}$ urban/industrial \\
\hline Acquarica del Capo & 0.55 & 0.52 & Monteroni di Lecce & 0.43 & 0.25 \\
\hline Alessano & 0.40 & 0.36 & Morciano di Leuca & 0.42 & 0.30 \\
\hline Alliste & 0.33 & 0.38 & Muro Leccese & 0.37 & 0.35 \\
\hline Aradeo & 0.35 & 0.40 & Nardò & 0.68 & 0.70 \\
\hline Calimera & 0.32 & 0.40 & Nociglia & 0.67 & 0.60 \\
\hline Campi Salentina & 0.81 & 0.80 & Novoli & 0.60 & 0.66 \\
\hline Caprarica di Lecce & 0.40 & 0.40 & Otranto & 0.21 & 0.20 \\
\hline Carmiano & 0.67 & 0.60 & Parabita & 0.40 & 0.36 \\
\hline Casarano & 0.65 & 0.60 & Patù & 0.34 & 0.33 \\
\hline Castrì di Lecce & 0.55 & 0.33 & Poggiardo & 0.60 & 0.53 \\
\hline Castro & 0.35 & 0.33 & Porto Cesareo & 0.70 & 0.65 \\
\hline Cavallino & 0.55 & 0.33 & Presicce & 0.46 & 0.40 \\
\hline Collepasso & 0.33 & 0.33 & Racale & 0.42 & 0.37 \\
\hline Copertino & 0.75 & 0.60 & Ruffano & 0.66 & 0.60 \\
\hline Corigliano d'Otranto & 0.33 & 0.33 & SanCesario di Lecce & 0.30 & 0.33 \\
\hline Corsano & 0.43 & 0.40 & San Donato di Lecce & 0.36 & 0.34 \\
\hline Cutrofiano & 0.45 & 0.40 & San Foca & 0.52 & 0.46 \\
\hline Galatina & 0.72 & 0.66 & San Pietro in Lama & 0.35 & 0.33 \\
\hline Galàtone & 0.60 & 0.66 & Salice salentino & 0.36 & 0.28 \\
\hline Gallipoli & 0.81 & 0.64 & San Cassiano & 0.73 & 0.45 \\
\hline Giurdignano & 0.68 & 0.50 & Sanarica & 0.31 & 0.28 \\
\hline Lecce & 0.74 & 0.63 & Scorrano & 0.68 & 0.66 \\
\hline Lequile & 0.55 & 0.41 & Soleto & 0.24 & 0.13 \\
\hline Leverano & 0.70 & 0.76 & Spongano & 0.39 & 0.38 \\
\hline Lizzanello & 0.52 & 0.66 & Squinzano & 0.65 & 0.52 \\
\hline Lucugnano & 0.55 & 0.50 & Sternatìa & 0.45 & 0.33 \\
\hline Maglie & 0.64 & 0.64 & Supersano & 0.56 & 0.53 \\
\hline Marina di Sant'Isidoro & 0.40 & 0.66 & Surbo & 0.55 & 0.47 \\
\hline Marina di Torre Lapillo & 0.81 & 0.80 & Taurisano & 0.52 & 0.46 \\
\hline Marittima di Diso & 0.37 & 0.50 & Trepuzzi & 0.54 & 0.47 \\
\hline Martano & 0.62 & 0.40 & Tricase & 0.60 & 0.62 \\
\hline Martignano & 0.43 & 0.48 & Tuglie & 0.39 & 0.46 \\
\hline Matino & 0.52 & 0.50 & Ugento & 0.62 & 0.70 \\
\hline Melendugno & 0.43 & 0.38 & Uggiano La Chiesa & 0.58 & 0.47 \\
\hline Melissano & 0.63 & 0.54 & Veglie & 0.57 & 0.58 \\
\hline Minervino di Lecce & 0,57 & 0,50 & Vèrnole & 0.63 & 0.68 \\
\hline
\end{tabular}

\section{Discussion and conclusions}

The methodology adopted for flood risk analysis in the Salento peninsula, according to the historical model and the study of DTM sequence, where the lowering zones affected by floodings can be seen, allows to identify the hazard and total risk areas in the study area. In particular, the DTM sequence shows an increase of the surface of the Graben structures and, therefore, an increase of the surface of the flooded areas. For example, in the time interval from 1956 to 1976, the Graben area included between the Supersano, Ruffano and Nociglia municipalities was increased by approximately $1 \mathrm{~km}^{2}$, such as calculated by the GIS software. In addition, during the same time interval, other lowering zones in the S. Eleuterio - Casarano - Taurisano Graben, such as the lowering zones of Poggiardo - Minervino di Lecce - Martano Graben, have increased their surface area because the allu- vium was accumulated from erosion by rainfall water impacting other zones (Figs. 3 and 8).

The application of this developed methodology can be considered to be quite satisfactory, given that the basic inventory maps were very good.

An inspection of Figs. 11 and 14 reveals that the flood hazard analysis has produced an inhomogeneous distribution of the flood risk values in the study area and, consequently, the highest values are located:

- In the graben area of the SW and SE (Fig. 15).

- Along the coast at W, from Torre del Pizzo (near Gallipoli town, Fig. 16) to Porto Cesareo, at NW and, furthermore, towards Torre Lapillo and Punta Prosciutto (NW part). 


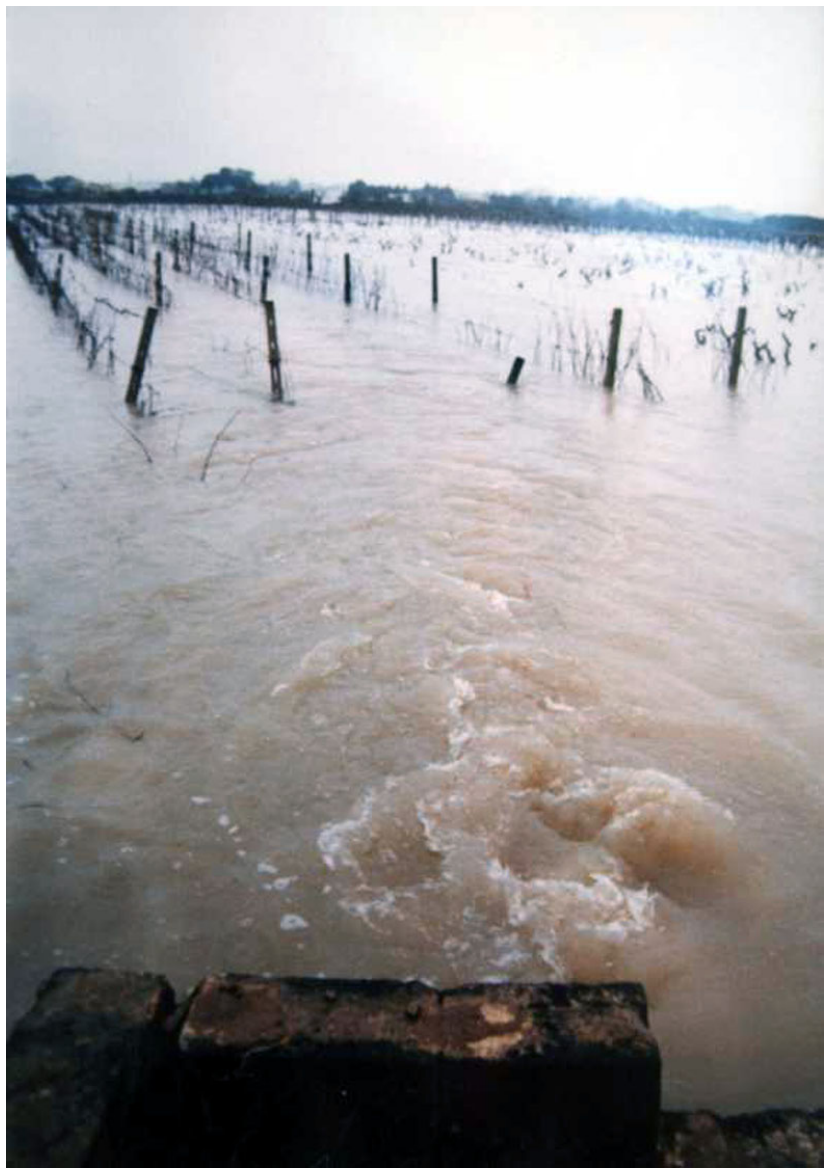

Fig. 15. Damages to agricultural area (vineyards) due to flash flood at Galàtone municipality.

The map processing and analysis show moderate to high values of flood risk, conferring a remarkable importance to the moderate class of risk, which represents almost $50 \%$ of the area. Just the Horst and NE areas show low and moderate to low values because the geological and geomorphological characteristics tend to prevent flood occurrences. Furthermore, since it was not possible to make forecasts for areas not struck by floods, it was hence not possible to assess the flood hazard and risk in these areas. Nevertheless, the study carried out at a scale of 1:25000, according to the guidelines of the Italian law 183/89 (Soil Defense), law 180/98 (mapping of areas at hydrogeological risk) and law 365/2000 (intervention measures of areas affected by floods), is an important tool that the government agencies should consider in order to correctly undertake management and intervention planning, whose purpose is to prevent and/or mitigate the flood risk.

In addition, with regard to the risk assessment of the elements involved, it is necessary to use detailed technical maps (with a scale of 1:5000) which are presently not available for the study area.

Often, however, these types of studies are not addressed to set - up an intervention policy to prevent and/or mitigate the flood risk. There are many reasons for this, often unjustified, which can be one or a combination of the following:

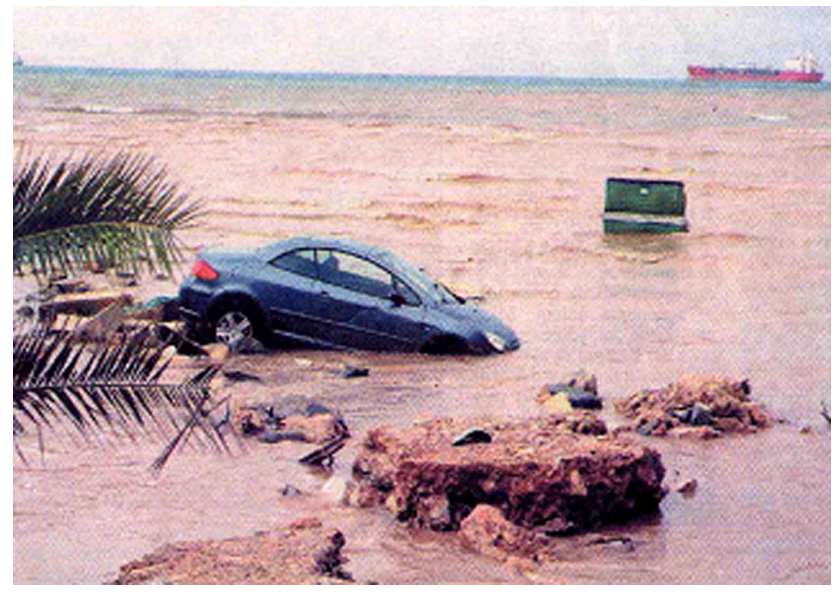

Fig. 16. Big flood at Torre del Pizzo, near Gallipoli municipality. Continental waters flow towards the sea, dragging cars and housescontent.

1) incorrect management of funds, 2) extended delay of the Government to set-up the different phases in an intervention planning and/or 3) negligence of the Government to enforce laws addressing environmental protection (ICGPSIA, 1995).

As a general rule, it is also opportune to consider the more catastrophic events in order to identify the behaviour of the floods and their interaction with the geological and geomorphological environment, analysing always the minimum thresholds of the precipitation and the way in which they manifest themselves.

Acknowledgements. The authors wish to thank the Municipal Technical Offices of Salento, the Provincial Firemen of Lecce town, the Department of Civil Protection, "Sigismondo Castromediano" Library of Lecce town and local/national Newspapers ("Quotidiano di Lecce", "Gazzetta del Mezzogiorno", "Il Messaggero" and "La Repubblica") for their interest, valuable comments and help obtaining information about the number of calamitous events occurred and rescue operations. The Reclamation Land Union "Ugento Li Foggi" and "Arneo", Directorate of Public Works, and the Hydrographic Survey of Bari assisted with the rainfall data processing.

Special thanks are also extended to ITC (International Institute for Geo-Information Science and Earth Observation) of Enschede, the Netherlands.

Edited by: M.-C. Llasat

Reviewed by: two referees

\section{References}

Andah, K. and Umbertini, L.: Confronting hydrogeological disaster in a vulnerable environment, in: Managing hydrogeological disasters in a vulnerable environment, edited by: Andah, K., CNR-GNDCI \& UNESCO, Int. Hydrogeol. Progr., Perugia, 3368, 1998.

Agency for Environmental Protection and for Technical Surveys: Department of Soil Defence, National Geological Survey (in Italian: APAT, DDS (SGI) (Agenzia per la Protezione dell' Ambiente e per i Servizi Tecnici, Dipartimento Difesa del Suolo, Servizio 
Geologico d'Italia)): Scheme of application form of "IFFI Project (Inventario Fenomeni Franosi in Italia)", Roma, 2001.

Arnell, N. W.: The effect of climate change on hydrogeological regimes in Europe: a continental perspective, Global Environ. Change, 9, 5-23, 1999.

Battista, C., Boenzi, F., Fiore, S., Novembre, D., Palmentola, G., and Pennetta, L.: Lineamenti geografici del Salento leccese, Conv. Ann. del Gr. Naz. di Geogr. Fis. e Geomorf., Lecce, 1985.

Battista, C., Pennetta, L., Specchio, V., and Zito, G. M.: L'aridità del suolo nella Penisola Salentina, Quad. Ric. Centro Studi Geot. Ing., Lecce, 11, 259-274, 1987.

Bersani, P.: Tiber River at Rome: summer Floods and considerations on the maximum historical discharge, J. Tech. Environ. Geol., CNG, 2, 2004.

Bissanti, A.: Le piogge in Puglia, Ann. Fac. Econ. e Comm. Univ. di Bari, 23, 90, Bari, 1968.

Bolt, B. A.: Geological hazards: Earthquakes, Tsunamis, Volcanoes, Avalanches, Landslides, Floods, Springer, Berlin, 8, 328 pp., 1975.

Carrozzo, M. T., Delle Rose, M., De Marco, M., Federico, A., Forte, F., Margiotta, S., Negri, S., Pennetta, L., and Simeone, V.: Pericolosità ambientale di allagamento nel Salento leccese, Quad. di Geol. Appl., Serie AIGA, Roma, 1, 77-85, 2003.

Carrozzo, M. T. and Ruggero, L.: Descrizione climatica e paleoclimatica della Puglia, Atti $1^{\circ}$ Workshop "Clima, Ambiente e Territorio nel Mezzogiorno”, Taormina, 31-41, 1989.

Ciaranfi, N., Pieri, P., and Ricchetti, G.: Note alla Carta Geologica delle Murge e del Salento, Mem. Soc. Geol. It., 41, 449- 460, 1988.

CNR (National Council of Research) - GNDCI (National Group for Hydrogeological Catastrophes Defence) (in Italian: CNR (Consiglio Nazionale delle Ricerche) - GNDCI (Gruppo Nazionale per la Difesa dalle Catastrofi Idrogeologiche)): AVI Project (Italian Vulnerable Areas): Census of Italian municipalities affected by landslides and floods, CNR, Perugia, 1998.

Coburn, A. W., Spence, R. J. S., and Pomonis, A.: Vulnerability and Risk Assessment, 2nd ed. Geneva: UNDP Disaster Management Training Programme, 69 pp., 1994.

Colamonico, C.: Aspetti geologici e geografici del Salento, Studi salentini, Galatina, 1, 11-19, 1956.

Colamonico, C.: Zone di piovosità e densità di popolazione nella Provincia di Lecce, Riv. Geogr. It., Firenze, Fig. 2, 24, 161-180, 1917.

Cook, J. L.: Quantifying peak discharges for historical floods, J. Hydrol., 37, 29-40, 1987.

Corine Project LU/LC (Land Use/Land Cover): Cartographical data of Land Use, 1999.

Costa, O. G.: Osservazioni meteorologiche fatte in Lecce (dal 1812 al 1824), Ann. Civ. Regno Due Sicilie, Napoli, 6, 5-10, (C 602), 1834.

Daniels, M. D.: Hydrological Applications of GIS, edited by: Gurnell, A. M. and Montgomery D. R., John Wiley and Sons, Chichester, 2000, 173 pages, Geomorphology, 54, 347-348, 2003.

De Giorgi, C.: Cenni di geografia fisica della provincia di Lecce, Tip. Ed. Salentina, Lecce, 1884.

De Giorgi, C.: Descrizione geologica e idrografica della provincia di Lecce, Ed. Salomi, Lecce, 1922.

De Giorgi, C.: Descrizione fisica geologica e idrografica della provincia di Lecce (a cura di A. Vignola), Centro Studi Sal., Tipografia Mariano, Galatina, 1960.

Downing, T. E.: Assessing socio - economic vulnerability to famine: frameworks, concepts and applications, FEWS Working
Paper 2.1. USAID, 102 pp., Washington, 1991

Forte, F.: GIS, aerial photos, remote sensing study for flood risk management and assessment, Case study of Salento peninsula, Southern Italy, $\mathrm{PhD}$ thesis in Geomorphology and Environmental Dynamics, 116 pp., Digilabs editor, Bari, 2005.

Gisotti, G. and Benedini, M.: Il dissesto idrogeologico: previsione, prevenzione e mitigazione del rischio. Nuova edizione aggiornata ed ampliata, Carocci editore, 595 pp., ill.; $24 \mathrm{~cm}$ - (Manuali del progettista (Carocci); 79), Roma, 2000.

Green, C. H. and Penning-Rowsell, E. C.: Flooding and the quantification of "intangibles", Journal of the Institution of Water and Environmental Management, 3, 27-30, 1989.

Hudson, P. F.: Floodplains: environment and process, Geomorphology, 56, 223-224, 2003.

ICGPSIA (Interorganizational Committee on Guidelines and Principles for Social Impact Assessment): Guidelines and Principles for Social Impact Assessment, EIA Review, 15, 11-43, 1995.

Johnston, A.: Geographic Information Systems in Ecology, Blackwell, Oxford, 1998.

Khan, S. D.: Urban development and flooding in Houston Texas, inferences from remote sensing data using neural network technique, Environ. Geol., 47, 1120-1127, 2005.

Landesman, L. Y.: Hazard assessment, Vulnerability analysis, Risk assessment and Rapid Health assessment, Public Health Management of Disasters, APHA, Washington DC, chapter 5, 57-72, 2001.

Largaiolli, T., Martinis, B., Mozzi, G., Nardin, M., Rossi, D., and Ungaro, S.: Note illustrative della Carta Geologica d'Italia Foglio 214 “'Gallipoli”, Serv. Geol. It., 64 pp., Roma, 1969.

Martinis, B.: Lineamenti strutturali della parte meridionale della Penisola Salentina, Geol. Rom., Roma, 1, 11-23, 1962.

Martinis, B.: Sedimenti calabriani sulle Serre Calaturo e Castelforte (Penisola Salentina), Riv. It. Paleont. e Strat. LXXIII, Milano, 1023-1038, 1967a.

Martinis, B.: Note geologiche sui dintorni di Casarano e Castro (Lecce), Riv. It. Paleont. e Strat. LXXIII,Milano, 1-64, 1967b.

Martinis, B.: Note illustrative della Carta Geologica d'Italia. Foglio 223 "Capo S. Maria di Leuca”, Serv. Geol. It., 64 pp., 1970.

Meijerink, A. M. J., De Brouwer, J. A. M., Mannaerts, C., and Valenzuela, C. R.: Flood study in the Meghna-Dhonagoda polder, Bangladesh, Introduction to the use of Geographic Information Systems for practical hydrology; UNESCO, International Hydrological Programme ITC, 2003.

Mijatovic, B. F.: Catastrophic flood in the polje of Cetinje in February 1986, a typical example of environmental impact of karst, Proceedings of "Karst hydrogeology: Engineering and environmental applications", Orlando, 299-303, 1987.

Molina, M. and McDonald, F.: Sinkhole management and flooding in Jamaica, Proceedings of "Karst hydrogeology: Engineering and environmental applications", Orlando, 293-298, 1987.

Newspaper "Il Messaggero": News about the floods occurred during the years 1968-2004, Roma.

Newspaper "La Gazzetta del Mezzogiorno": News about the floods occurred during the years 1968-2004, Bari.

Newspaper "La Repubblica": News about the floods occurred during the years 1968-2004, Roma.

Newspaper "Quotidiano di Lecce": News about the floods occurred during the years 1968-2004, Lecce.

OFDA (Office of the US Foreign Disaster Assistance): Disaster history, significant data on major disasters worldwide, 1900-1995, US Agency for International Development, Washington, 265 pp., 1996. 
Ricchetti, G.: Carta Geomorfica del Salento Meridionale, Quad. Ric. Centro Studi Geot. Ing., 11, Lecce, 1988.

Spaliviero, M.: Historic fluvial development of the Alpine - foreland Tagliamento River, Italy, and consequences for floodplain management, Geomorphology, 52, 317-333, 2003.

Wang, R., King, L., and Jiang, T.: Flood vulnerability analysis and hazard management, Supported by GIS and remote sensing, Natural hazard Conference, Enschede, The Netherlands, 1999.
Zito, G. M., Ruggiero, L., and Zuanni, F.: Zone climatiche omogenee in Puglia, Atti $2^{\circ}$ Colloquio "Approcci metodologici per la definizione dell'Ambiente fisico e biologico del Mediterraneo", Lecce, 15-40, 1988.

Zito, G. M., Ruggiero, L., and Zuanni, F.: Aspetti meteorologici e climatici della Puglia, Atti $1^{\circ}$ Workshop "Clima, Ambiente e Territorio nel Mezzogiorno, Lecce, 1989. 